\title{
Do children walk where they bike? Exploring built environment correlates of children's walking and bicycling
}

\author{
Mika Moran \\ Technion-Israel Institute of Technology \\ moran.mika@gmail.com
}

Orna Baron-Epel

The University of Haifa

ornaepel@research.haifa.ac.il

\author{
Pnina Plaut \\ Technion-Israel Institute of Technology \\ pninapl1@gmail.com
}

\begin{abstract}
Previous studies examined environmental correlates of children's physical activity. While most of these studies used aggregated physical activity measures (i.e., overall physical activity, active travel), little is known about the contribution of specific environmental attributes to specific types of physical activity. This study examined associations between GIS-based environmental measures and children's selfreported walking and bicycling. The study area included "traditional neighborhoods" ( $\mathrm{N}=4)$, characterized by high-density, land-use mix and grid-street network, and "suburban neighborhoods" $(\mathrm{N}=3)$, characterized by low-density, land-use segregation, and cul-de-sac streets. Data on children's physical activity and psychosocial and socio-demographic factors were obtained through a school survey (of fifth and sixth graders) ( $\mathrm{N}=573)$. Urban-form measures (intersection density, residential density, and built coverage) were significantly positively associated with walking and negatively associated with bicycling. These associations remained significant after controlling for social, intra- and inter-personal factors. These findings suggest that certain environments may encourage children's walking and hinder their bicycling at the same time (and vice versa) and therefore raise the need for a more clear distinction between child-related walkability and bikeablilty.
\end{abstract}

Keywords: children, walking, bicycling, built environment, urban form

\section{Introduction}

Children's physical inactivity is a major burden on public health worldwide, due to its established association with current escalating trends of childhood and adolescent obesity (Tremblay and Willms 2003; Parsons et al. 1999; Raitakan et al. 1994). In recent years, the levels of physical activity and active

Copyright 2015 Mika Moran, Pnina Plaut, \& Orna Baron-Epel

http://dx.doi.org/10.5198/jtlu.2015.556

ISSN: 1938-7849 | Licensed under the Creative Commons Attribution - Noncommercial License 3.0

The Journal of Transport and Land Use is the official journal of the World Society for Transport and Land Use (WSTLUR) and is published and sponsored by the University of Minnesota Center for Transportation Studies. This paper is also published with sponsorship from WSTLUR and the Institutes of Transportation Studies at the University of California, Davis, and the University of California, Berkeley. 
transport are decreasing in many Western countries (Holt et al. 2007; Staunton, Hubsmith, and Kallins 2003; Timperio et al. 2004). In the United States only one in nine children walks or rides a bicycle to school (Staunton, Hubsmith, and Kallins 2003).

Adoption of an active lifestyle in childhood and adolescence can affect quality of life throughout later life. Studies show that children who are physically active are more likely to maintain an active lifestyle through their adulthood (Raitakan et al. 1994). Moreover, being active during childhood was found to decrease several health risk factors, such as obesity (Parsons et al. 1999; Raitakan et al. 1994), metabolic syndrome (Brage et al. 2004; Ekelund et al. 2006), and clustering of risk factors for cardiovascular diseases (Ekelund et al. 2007).

Although walking and bicycling often suffer from a negative image (Underwood et al 2014), they are considered to be two types of physical activity that are the easiest to adopt and adhere to. This is attributed to their low level of exertion, the fact that they can be performed for both utilitarian and leisure purposes; and the relatively few barriers imposed on participants (e.g., not significantly time consuming, doesn't include high-intensity workout) (Frank, Engelke, and Schmid 2003). Compared to biking, walking is even easier to adopt and adhere to as it requires no equipment and thus has zero cost. In addition to their health benefits, walking and bicycling were found to have positive effects on children's development of independence, improved self-image, social ties, adoption of physical activity behavior, and decreased dependence on cars for transportation (Timperio et al. 2004).

Previous studies examined environmental correlates of children's physical activity. While most of these studies used aggregated physical activity measures (e.g., overall physical activity, active travel), little is known about the contribution of specific environmental attributes to specific types of physical activity among children. This study examined associations between GIS-based environmental measures and children's self-reported walking and bicycling for different purposes (travel, leisure).

The following section summarizes previous research on the associations between the built environment and active living. Section 3 presents the methodology and data analysis in detail. Results are presented and interpreted in Section 4. Sections 5 and 6 offer discussion followed by conclusions and recommendation for future research.

\section{$2 \quad$ Literature review}

\subsection{Background}

Toward the end of the 20th century an interdisciplinary field emerged that deals with the built environment and active living, including walking, bicycling, and other forms of physical activity. The motivations behind this field include health and environmental concerns about physical inactivity and chronic diseases, on the one hand, and high car-dependency and traffic-related pollution, on the other. Correspondingly, the need to reclaim urban space for pedestrians and bicyclists led to the development of various planning approaches, such as: "Healthy-Active City" (Edwards and Tsouros 2008), "Smart Growth" (Frumkin, Frank, and Jackson 2004), "Transit Oriented Development" (TOD) (Cervero 1998), and "New Urbanism" (Duany and Plater-Zyberk 1992; Calthorpe 1993; Audirac and Shermyen 1994). All of the aforementioned planning approaches seek to adjust and adapt the physical urban environment to promote and enhance walking, bicycling, and other modes of non-motorized transportation. These initiatives were followed by empirical studies relating the built environment with physical activity, as described below. 


\subsection{The built environment and physical activity}

Ecological models suggest that physical activity and active living are related to factors on various scales and levels: environmental, social, inter-personal, and intra-personal (Edwards and Tsouros 2006; McLeroy et al. 1988; Sallis and Owen, 1990; Sallis et al. 2006; Stokols 1992). In recent years, a growing body of empirical evidence supports associations between the built environment and active living. The concept of walkability is used frequently in the literature to define overall support for pedestrian and bicyclist travel, and it is often marked by numerous environmental variables, such as mixed land use, density, streets connectivity, and pedestrian amenities (Frank, Engelke and Schmid 2003; Sallis et al. 2006; TRB 2005).

While some studies examined the impact of specific environmental attributes on physical activity, other studies examined the impact of a combination of several environmental attributes by creating composite measures. An example of such a composite measure is manifested in the walkability index (Frank et al. 2010), which includes residential density, retail floor area ratio, intersection density, and land-use mix.

Composite environmental measures may provide a good representation of the environment given that different environmental attributes usually tend to appear together. For example, areas with high residential densities tend to be more interconnected and to include a high mix of different land uses. On the other hand, examining specific environmental attributes separately may help identify the unique contribution of each attribute on its own to physical activity and hence may be more easily translated into planning recommendations. Recently, researchers and practitioners have raised the need for identifying specific environmental attributes that enhance physical activity (Sallis 2008).

Studies that used a walkability index found it to be associated with travel walking (Heath et al. 2006; Manaugh and El-Geneidy 2011; Transportation Research Board 2005) but not with leisure walking or total physical activity (Owen et al. 2004; Saelens and Handy 2008). Other studies found that different environmental attributes were related to different types of physical activity. Specifically, leisure walking and exercise were found to be related to characteristics of parks and recreational facilities (e.g., accessibility, quality, and maintenance of facilities) (Sugiyama and Thompson 2008; Reed et al. 2008; McCormack et al. 2010). Travel walking was found to be related mainly to street connectivity and high access to commercial destinations (Cerin et al. 2007; Lee and Modoun 2006; McConville et al. 2011). Many of the studies among adults focused on environmental correlates of walking, but recently the number of such studies on bicycling is increasing. These studies' findings suggest that bicycling is positively associated with bicycle infrastructure (Dill 2009; Moudon et al. 2005) but also with walkability variables, such as dwelling density, street connectivity, land-use mix, and net retail area ratio (Owen et al., 2010).

Overall, results of research to date indicate that different types of physical activity (e.g., walking, bicycling) performed for different purposes (e.g., travel, leisure) are related to different environmental attributes. In addition to this, the associations between the built environment and physical activity may vary across the lifespan due to the changes in environmental needs for active living in different stages of life (e.g., childhood vs. adulthood). For example, living in a suburb may enhance outdoors activities among children and at the same time hinder travel walking among their parents (due to landuse segregation and multiple cul-de-sac streets, which increase distances to daily destinations). Overall, extensive literature exists on environmental correlates of physical activity, including studies from both travel behavior and physical activity literature (e.g., Heath et al. 2006; McCormack et al. 2010; Saelens and Handy 2008). However, there are important gaps in this emerging literature, one of which is being addressed in this paper concerning environmental correlates of specific types of physical activity among children. 


\subsection{The built environment and children's physical activity}

Similar to the findings among adult populations, children's active travel was found to be positively associated with street connectivity and accessibility to daily destinations (Braza 2004; Ewing, Schroeer, and Greene 2004; Timperio et al. 2006), while children's recreational activity (consisting mainly of outdoors play) was found to be associated with high access to well-maintained recreational facilities (Sallis and Glanz 2006; Holt et al. 2008; Roemmich et al. 2007). In addition, children's walking and bicycling were found to be related to various environmental attributes, such as pedestrian and bicyclist infrastructure, street connectivity, and green open spaces (Davison and Lawson 2006; Ferreira et al. 2007; Sallis, Pruchaska, and Taylor 2000). Additional environmental attributes that were found to be important for children's physical activity include measures of road safety (e.g., traffic volume, presences of cross walks) and crime-related safety (e.g., street lights, presence of strangers) (Boarnet et al. 2005; Sallis and Glanz 2006; Timperio et al. 2004; Timperio et al. 2006).

To date, only a few studies focused solely on children's biking as outcome measures, and their findings are inconsistent. For example, the association between children's biking and street connectivity was found to be positive in one study (Trapp et al. 2011) but negative in another (Van Dyck et al. 2009). Other studies found no associations between environmental measures and children's biking (e.g., Ducheyne et al. 2013; de Meester et al. 2012; de Vries et al. 2010).

Many of the studies among children used aggregate outcome measures, such as "walking or bicycling to school" (Boaronet et al. 2005; Ewing, Schroeer, and Greene 2004; Timperio et al. 2006), "walking or bicycling to different destinations" (Carver et al. 2005; Timperio et al. 2004), and "active travel to school" (Larsen et al. 2009). These types of measures do not distinguish between different kinds of walking and bicycling that might differ in their environmental correlates. Therefore, little is known about the contribution of specific environmental attributes to specific types of walking and bicycling among children. The present study addresses this issue by examining environmental associations with children's neighborhood walking and bicycling for different purposes.

The main objective of this study is to examine the associations between specific measures of the built environment with walking and bicycling for travel and/or leisure among children (aged 10-12) in an urban setting in Israel. Specific objectives are: (1) to match specific built-environmental attributes (e.g., residential density, street connectivity) with specific components of active living (e.g., walking, bicycling for travel/leisure), and (2) to identify environmental correlates of childrens' walking and bicycling, while controlling for social, inter-, and intra-personal factors.

\section{$3 \quad$ Methodology}

\subsection{Study design}

The study was conducted in the city of Rishon LeZion, the fourth largest city in Israel $(228,200$ inhabitants), located along the central Israeli Coastline plain, 12 kilometers south of Tel Aviv. This study employs a cross-sectional design, including an environmental sampling approach, according to environmental attributes. Based on GIS analysis, seven neighborhoods in the city of Rishon LeZion were selected to include two types: "traditional neighborhoods" $(\mathrm{N}=4)$, characterized by high-density, landuse mix, and grid-street network, and "suburban neighborhoods" $(\mathrm{N}=3)$, characterized by low-density, land-use segregation, and cul-de-sac streets. It should be noted that all seven neighborhoods are located within the city.

The differences in urban form between the two neighborhood types can be explained by the historical context in which these neighborhoods were developed. The traditional neighborhoods were devel- 
oped during the 1930s through the1950s (Rishon LeZion municipality 2009). During those years, the most common urban design used in Israel consisted of "orthogonal street patterns" — an urban design style consisting of grid-street network streets and square/rectangular lots in which houses were aligned in rows with each other and with the street (Tzafrir-Reoven 2006). The suburban neighborhoods were developed much later, during the 1990s and 2000s (Rishon LeZion municipality 2009). In those years the dominant urban design used in Israel consisted of "picturesque patterns" - consisting of dendritic street layouts with multiple cul-de-sac streets, which create a geometrical form that is easily identified from an aerial view (e.g., circle, ellipse, star) (Tzafrir-Reoven 2006).

Figure 1 presents a map of the study area and the traditional and suburban neighborhoods. GIS analysis was conducted to obtain objective measures of the built environment (see Section 3.2). Data on children's physical activity and other social, inter- and intra-personal factors were obtained through a school survey (among fifth and sixth graders) (see Section 3.3).

The two areas (traditional and suburban) were chosen so as to have similar socioeconomic indicators, including the percent of participants in the labor force (97.3-98.4 percent in traditional neighborhoods, and 97.4-98.8 percent in suburban neighborhoods), and the percent of recipients of an undergraduate academic degree (24.6-31.4 percent in the traditional neighborhoods and 23.4-30.7 percent in the suburban neighborhoods). Also, there is no public housing in any of the case-study neighborhoods.

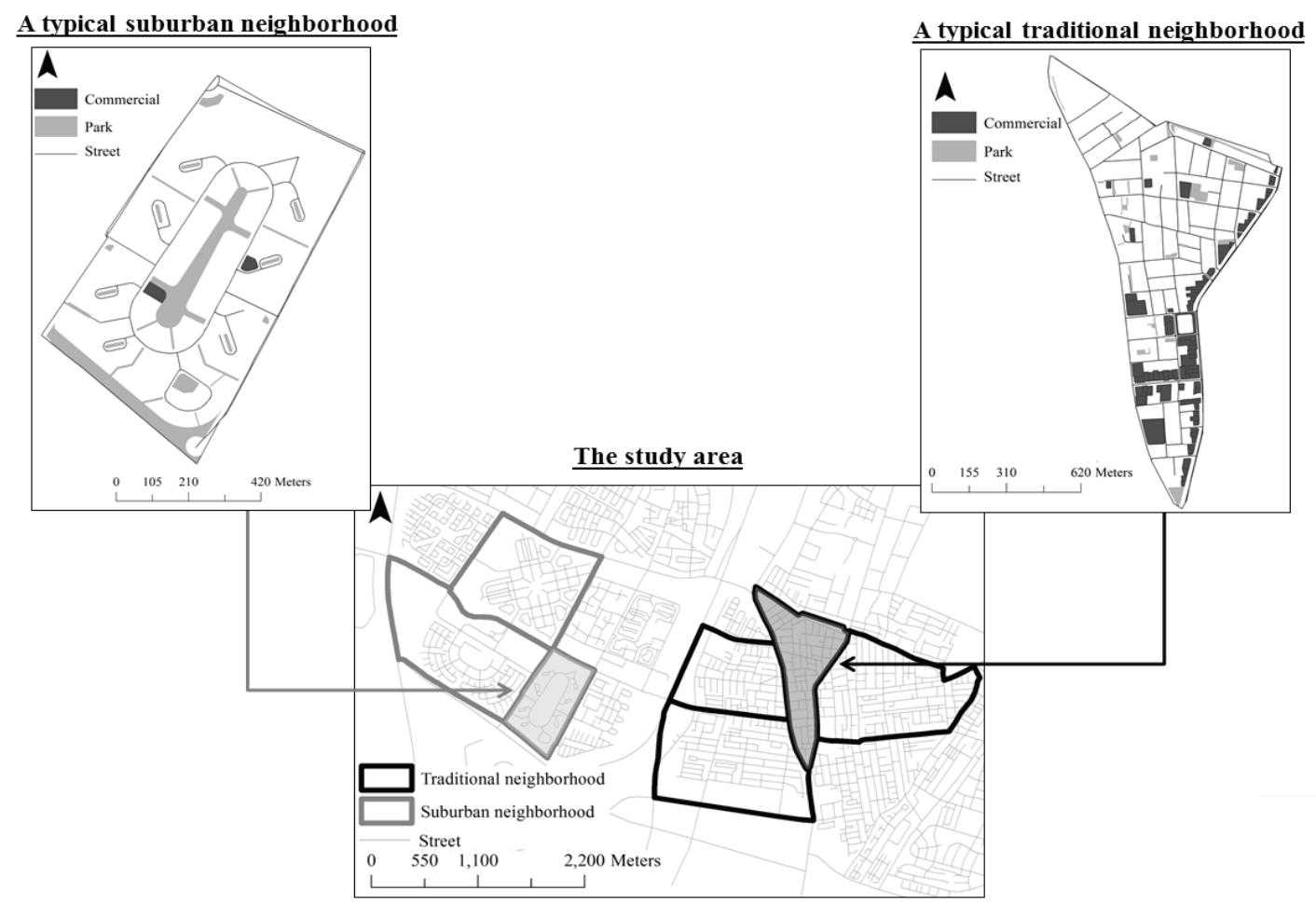

Figure 1: Maps of the two neighborhood types

\subsection{GIS procedure and analysis}

Objective measures of the built environment were obtained through GIS analysis (ESRI ArcGIS 9.3) in a disaggregate approach based on each participant's household location. Two types of environmental measures were created, including urban-form measures on the one hand and accessibility measures to daily destinations on the other. 
Urban-form measures included residential density (number of households per square kilometer), built coverage (overall built area per built lots area), and street connectivity (number of intersections per square kilometer). These urban-form measures were examined given their positive association with walking, which was observed in previous studies (e.g., Leslie et al. 2007; Moudon et al. 2006). All urbanform measures were calculated within a 400-meter airline buffer from each respondent's home. The areal unit chosen to examine the environmental variables may impact the findings (Mitra and Buliung 2012). In this study the choice of a 400-meter buffer was made because this buffer size covers the respondent's neighborhood area and hence reflects the environmental features within the respondent's neighborhood. In most cases a 400-meter buffer was located within the respondent's neighborhood, while larger buffers extended beyond the neighborhood boundaries. In addition, this spatial unit is consistent with previous studies that examined children's school-travel behavior (McMillan 2007; Mitra and Buliung 2014). Accessibility measures included the route distance from the respondent's home to three daily destinations, including the respondent's school, the nearest park, and the nearest store. These urban-form measures were examined due to their expected association with the outcome measures (see Section 3.4).

Table 1 shows descriptive statistics of the environmental measures and provides several differences between traditional and suburban neighborhoods. As shown in Table 1, all urban-form measures (street connectivity, residential density, and built coverage) are significantly (nearly two times) higher in traditional neighborhoods, reflecting their compact urban form compared to a sprawling urban form of suburban neighborhoods. While the mean route distance to the nearest store was significantly longer in suburban neighborhoods (289 meters vs 120 meters), the mean route distance to the nearest park was significantly shorter in suburban neighborhoods (96 meters vs 246 meters). No significant differences were observed in the mean route distance to school between the two neighborhood types. These differences reflect a relatively high accessibility of stores in traditional neighborhoods and a relatively high accessibility of parks in suburban neighborhoods.

Table 1: Environmental variables as measured at the individual level

\begin{tabular}{|c|c|c|c|c|c|c|c|c|c|}
\hline & \multicolumn{2}{|c|}{$\begin{array}{l}\text { Overall } \\
\text { sample }\end{array}$} & \multicolumn{2}{|c|}{$\begin{array}{c}\text { Traditional } \\
\text { neighborhoods }\end{array}$} & \multicolumn{2}{|c|}{$\begin{array}{c}\text { Suburban } \\
\text { neighborhoods }\end{array}$} & \multirow[b]{2}{*}{$\mathrm{t}$} & \multirow[b]{2}{*}{$\mathrm{df}$} & \multirow[b]{2}{*}{$\mathrm{P}$} \\
\hline & $\begin{array}{c}\text { Mean } \\
(\mathrm{SD})\end{array}$ & IQR & $\begin{array}{c}\text { Mean } \\
\text { (SD) }\end{array}$ & IQR & $\begin{array}{c}\text { Mean } \\
\text { (SD) }\end{array}$ & IQR & & & \\
\hline \multicolumn{10}{|c|}{ Urban form measures* } \\
\hline $\begin{array}{c}\text { Street connectivity } \\
\text { (intersections/ } \\
\text { sq km) } \\
\end{array}$ & $\begin{array}{c}86.22 \\
(33.50)\end{array}$ & $\begin{array}{l}59.71- \\
113.46\end{array}$ & $\begin{array}{l}111.84 \\
(24.64)\end{array}$ & $\begin{array}{l}95.54- \\
133.36\end{array}$ & $\begin{array}{c}61.23 \\
(18.98)\end{array}$ & $\begin{array}{l}43.79- \\
73.65\end{array}$ & 25.98 & 571 & $<0.0001$ \\
\hline $\begin{array}{l}\text { Residential density } \\
\text { (households/sq km) }\end{array}$ & $\begin{array}{l}11,240 \\
(4,580)\end{array}$ & $\begin{array}{l}7,498- \\
15,772\end{array}$ & $\begin{array}{l}15,180 \\
(2,880)\end{array}$ & $\begin{array}{c}13,448- \\
17,010\end{array}$ & $\begin{array}{c}7,400 \\
(1,830)\end{array}$ & $\begin{array}{l}5,503- \\
9,001\end{array}$ & 36.40 & 571 & $<0.0001$ \\
\hline $\begin{array}{l}\text { Built coverage (built } \\
\text { cover/built lots) }\end{array}$ & $\begin{array}{c}0.32 \\
(0.10)\end{array}$ & $0.22-0.41$ & $\begin{array}{l}0.40 \\
(0.05)\end{array}$ & $0.36-0.45$ & $\begin{array}{c}0.24 \\
(0.05)\end{array}$ & $0.20-0.28$ & 37.65 & 571 & $<0.0001$ \\
\hline \multicolumn{10}{|c|}{ Land use accessibility measures (meters)** } \\
\hline $\begin{array}{c}\text { Route distance to } \\
\text { school }\end{array}$ & $\begin{array}{c}472.42 \\
(272.87)\end{array}$ & $\begin{array}{c}269.19- \\
606.11\end{array}$ & $\begin{array}{c}425.21 \\
(230.75)\end{array}$ & $\begin{array}{c}253.76- \\
566.81\end{array}$ & $\begin{array}{c}518.49 \\
(301.82)\end{array}$ & $\begin{array}{l}313.00- \\
663.41\end{array}$ & -2.04 & 569 & 0.06 \\
\hline $\begin{array}{l}\text { Route distance to near- } \\
\text { est store }\end{array}$ & $\begin{array}{c}205.17 \\
(179.93)\end{array}$ & $\begin{array}{l}59.64- \\
310.26\end{array}$ & $\begin{array}{l}119.92 \\
(89.39)\end{array}$ & $\begin{array}{l}51.23- \\
177.44\end{array}$ & $\begin{array}{c}289.19 \\
(205.57)\end{array}$ & $\begin{array}{l}92.27- \\
435.55\end{array}$ & -6.35 & 564 & $<0.0001$ \\
\hline $\begin{array}{l}\text { Route distance to near- } \\
\text { est park }\end{array}$ & $\begin{array}{c}170.61 \\
(129.40)\end{array}$ & $\begin{array}{l}68.57- \\
261.95\end{array}$ & $\begin{array}{c}246.62 \\
(129.59)\end{array}$ & $\begin{array}{l}146.39- \\
348.64\end{array}$ & $\begin{array}{c}95.67 \\
(73.50)\end{array}$ & $\begin{array}{l}42.59- \\
131.43\end{array}$ & 13.68 & 566 & $<0.0001$ \\
\hline
\end{tabular}

* measured within a $400 \mathrm{~m}$ radius from the respondents' home

** measured route distance from the respondents' home to each destination 
The fact that the home-school distance is similar in traditional and suburban neighborhoods can be attributed to national school policy and to the neighborhoods' demographic profiles. In both neighborhood types the proportion of primary-school-aged children (6-to 12-year-olds) is relatively similar (7-8 percent in traditional and 11-13 percent in suburban neighborhoods) (Rishon LeZion municiplity 2013). According to Israeli school registration regulations (Israeli Education Law 1959), elementary schools should be located within walking distance from the pupils' homes (defined as up to 2 kilometers for first through fourth graders and up to 3 kilometers for fifth and sixth graders, aged 10-12). It is noteworthy that given the relatively high density in our study area, schools were located much closer to pupils' homes (around 0.5 kilometers on average in both traditional and suburban neighborhoods).

Correlation analysis was conducted to identify spatial co-variability of environmental measures. The three urban-form measures — street connectivity, residential density, and built coverage-were strongly positively correlated (with correlation coefficients ranging from $0.48-0.80$ at a significance level of $\mathrm{p}<0.0001$ ). On the other hand, accessibility measures were only weakly to moderately correlated to each other. Interestingly, the three urban-form measures were negatively correlated with the distance to the nearest store (with correlation coefficients ranging from -0.24 to -0.48 at a significance level of $\mathrm{p}<0.0001$ ) and positively correlated with the distance to the nearest park (with correlation coefficients ranging from $0.28-0.54$ at a significance level of $\mathrm{p}<0.0001$ ). These correlations reflect the environmental attributes of the study area: On the one hand, traditional neighborhoods — characterized by a compact urban form (high levels of all three urban-form measures), high accessibility of stores, and low accessibility of parks. On the other hand, suburban neighborhoods - characterized by a sprawling urban form (low levels of all three urban-form measures), high accessibility of parks, and low accessibility of stores.

\subsection{Survey procedure and analysis}

The study population consisted of children aged 10-12 years, who live in the city of Rishon LeZion (in both traditional and suburban neighborhoods). We chose to focus on this age group because 10-to 12-year-old children tend to walk, bicycle, or "hang out" within their neighborhoods (10-15 minutes walking distance from home), unlike younger children who are more confined to their home surroundings or older children who travel farther beyond their neighborhood boundaries. Therefore, we assumed that this age group would enable us to examine the associations between the neighborhood environment and neighborhood walking and bicycling.

Within each neighborhood one primary school was chosen to participate in the survey (overall seven schools). Four classes per school participated in the survey, including two fifth grade and two sixth grade classes. The school surveys were conducted September 2010 through January 2011. Prior to the survey, school principals and teachers were provided with information regarding the study, and two weeks before the survey a passive consent letter was sent to parents. Ethics approval was received from the Technion Ethics Committee and from the Israeli Ministry of Education.

The self-administered questionnaires were completed in classrooms under exam-like conditions. For each class, three investigators plus the classroom teacher were in attendance to give assistance to the children when required. To ensure that the questions were understood and answered accurately as intended, the first author (MM) gave instructions and read the questionnaire out loud, while two research assistants provided students with individual help when needed.

Overall, 823 children participated in the survey, but only 573 were found eligible to be included in the analysis. A total of 250 respondents were excluded from the analysis due to various reasons that made it difficult to impossible to evaluate their everyday living environment through GIS. These cases included respondents who did not report their accurate address $(n=18)$, respondents living outside of the study area $(n=143)$, respondents whose parents were separated and hence spent half of the week 
outside of the neighborhood ( $\mathrm{n}=79$ ), and respondents who were new in the study area (moved in within a year before the survey) $(\mathrm{n}=10)$.

\subsection{Survey measures}

The survey questionnaire was developed based on existing literature and pilot tested among 60 pupils (30 fifth graders and 30 sixth graders) from two out of the seven schools participating in the study (one school located in a traditional neighborhood and the other school located in a suburban neighborhood). The questionnaire included questions regarding physical activity and other social, inter- and intra-personal variables known to be related to children's physical activity.

\subsubsection{Walking and bicycling}

The survey contained questions regarding walking to school and afternoon neighborhood walking and bicycling for various purposes. Walking to school was assessed through a single question regarding how many days in a regular week the child walks to school. Children were also asked about walking from school back home and about bicycling to and from school. However, these activities weren't included in the analysis due to their frequencies: Walking from school back home (four times a week) was reported by nearly all of the respondents ( 88 percent), while bicycling to and from school (four times a week) was reported by nearly none of the respondents (1 percent).

Additional questions focused on how often the child walks or bikes in the afternoon for leisure and to various destinations (store, park, friend's house). Children were able to select one of the four options: "never," "once in two weeks at most," "one to two times a week," and "at least three times a week." Based on the respondents answers, four dichotomous dependent variables were created: (1) walking to school, defined as "walks to school at least four times a week" ( $0=$ no/ $1=y e s)$; (2) afternoon walking to neighborhood destinations, defined as "walks to neighborhood destinations (a store or a friend's house) at least three times a week" ( $0=\mathrm{no} / 1=\mathrm{yes})$; (3) afternoon bicycling to neighborhood destination, defined as "bikes to neighborhood destinations (a store or a friend's house) at least one time a week " $(0=\mathrm{no} / 1=\mathrm{yes})$; and (4) afternoon bicycling for leisure, defined as "bikes for leisure (at a park or in the neighborhood) at least one time a week" ( $0=$ no/1=yes). Each activity variable was defined based on its frequency in the study sample. Given the high frequency of walking relatively to bicycling, walking variables consisted of walking at least three to four times a week, while bicycling variables consisted of bicycling at least once a week. These variables seem to represent health enhancing walking and bicycling. Compared to walking, bicycling requires higher physical exertion and thus it is reasonable to assume that lower frequencies of bicycling (e.g., once a week) would have a comparable health impact as higher frequencies of walking (e.g., three to four times a week). And indeed, several previous studies focused on bicycling at least once a week (Gil and Handy 2008; Moudon et al. 2005; Owen et al. 2010).

\subsubsection{Psychosocial factors (social, inter-, and intra-personal factors)}

The survey included questions regarding several psychosocial variables at various levels, including social community characteristics (social level), children's independent mobility (inter-personal level), perceived environment, travel preferences, and socio-demographic factors (intra-personal level). Most of these questions referred to the neighborhood environment defined as an area within a 10-minute walk around the respondent's home.

Social factors included two variables reflecting the respondent's acquaintance with other children living in his or her neighborhood on the one hand and the frequency of other children's outdoors play 
on the other. Respondents were given two statements to which they were asked to agree or disagree. These statements included: "I know many children who live in my neighborhood" and "In my neighborhood many children can be seen playing outside." It is noteworthy that some variables could be classified as both social and inter-personal. For instance, the respondent's acquaintance with other children living in his or her neighborhood could also be classified as inter-personal. However, for the sake of this study, the authors decided to classify this variable as social.

Inter-personal factors included the children's independent mobility by foot or by bike. Independent mobility was defined as the extent to which the child is allowed by his or her parents to walk or bike alone in the neighborhood environment (Tranter and Whiteleg 1994). Correspondingly, based on the respondents' answers to the survey, the following two variables were created: (1) Independent mobility by foot, defined dichotomously as either "high" or "low"; respondents were classified as having "high independent mobility by foot" if they reported "being regularly allowed to walk alone during daytime and nighttime"; (2) Independent mobility by bicycle, defined dichotomously as either "high" or "low"; respondents were classified as having "high independent mobility by bicycle" if they reported "being regularly allowed to bike alone during the daytime."

Intra-personal factors included perceptions regarding the neighborhood environment, travel preferences, and socio-demographic characteristics. Perceptions regarding the neighborhood environment were assessed through a series of statements to which the respondents were asked to agree or disagree. Based on the respondents' answers, the following composite variables were created: (1) Perceived environmental child-friendliness, respondents were given five statements regarding the extent to which their neighborhood is child friendly with which they were asked to agree or disagree. The five statements yielded high intra-class reliability (Cronbach's Alpha $=0.6, \mathrm{~N}=573$ ). Based on the respondents' answers, an ordinal variable was created with values ranging from 0 to 5 , where $0=$ "the neighborhood environment is perceived as not at all child-friendly," and 5 = "the neighborhood environment is perceived as very child-friendly." (2) Perceived crime-related safety-respondents were given two statements regarding the extent to which they feel safe in their neighborhood with which they were asked to agree or disagree. The respondents' answers to these two statements were positively correlated (Spearmans' rho = $0.45, \mathrm{p}<0.0001, \mathrm{~N}=561)$. Based on the respondents' answers, an ordinal variable was created with values ranging from 0 to 2 , where 0 = "feels unsafe in the neighborhood," and 2 = "feels safe in the neighborhood."

Travel preferences were assessed through a series of statements with which the respondents were asked to agree or disagree. Based on the respondents' answers, two dichotomous measures were created: (1) Pro-walking-respondents were classified as "pro-walking" if they agreed with the following two statements: "I like walking" and "When possible (due to short distances), I prefer to walk than to travel by car." 'The respondents' answer to these two statements were positively correlated (Spearmans' rho = 0.40, $\mathrm{p}<0.0001, \mathrm{~N}=565)$. (2) Pro-biking-respondents were classified as "pro-biking" if they agreed with the following two statements: "I like bicycling" and "When possible (due to short distances), I prefer to ride a bike than to travel by car." The respondents' answer to these two statements were positively correlated (spearmans' rho $=0.35, \mathrm{p}<0.0001, \mathrm{~N}=506$.)

Finally, the survey contained a few questions regarding socio-demographic characteristics, which served as control variables, including gender, grade, and number of cars per household.

\subsection{Statistical analysis}

Statistical analyses were performed using SPSS version 16.0. First, conventional descriptive statistics were used to describe the GIS and survey measures. Then, bivariate and multivariate logistic regression models were used to assess correlates of the four outcome measures. The independent variables were 
classified into the following four groups: environmental, social, inter-, and intra-personal factors. For all regression analyses, continuous environmental variables (urban form and accessibility variables) were transformed into natural logarithms. To minimize the potential multi-colinearity, the strongest environmental predictors in the bivariate analysis were included in the multivariate models consisting of one urban form and one accessibility measure.

\section{$4 \quad$ Results}

Table 2 presents descriptive statistics of self-reported walking and bicycling and psychosocial and sociodemographic variables. Walking to school was found to be the most common form of active transportation (and related physical activity) among children (reported by 69.5 percent of the respondents), while afternoon bicycling to neighborhood destinations was the least common (reported by only 35 percent). Regarding psychosocial factors, social factors were the most common (reported by 83-88 percent of the respondents), while individual's travel preferences were the least common (reported by about 44 percent). Children's independent mobility was more common when reporting mobility by foot than by bike (62.3 percent vs 42.3 percent). Regarding perceived environment factors, the average score of perceived environmental child-friendliness was relatively higher than that of perceived crime-related safely (3.84 out of 5 vs. 1.03 out of 2). The proportions of boys and girls and fifth and sixth graders were nearly identical. Most of the respondents owned a bicycle and had at least one car in their household.

Table 3 presents bivariate analysis to predict walking and bicycling by the four groups of independent variables: environmental, social, inter-personal factors, and intra-personal factors.

Overall, walking to school was more common in traditional neighborhoods, while bicycling (to neighborhood destinations and for leisure) was more common in suburban neighborhoods. Specifically, walking to school was significantly more common in traditional neighborhoods (81 percent vs. 59 percent, $\chi^{2}=25.91, \mathrm{p}<0.0001$ ), while afternoon bicycling for travel and leisure was significantly more common in suburban neighborhoods ( 42 percent vs. 26 percent, $\chi^{2}=12.69, \mathrm{p}<0.0001$ and 59 percent vs. 42 percent, $\chi^{2}=12.80, \mathrm{p}<0.0001$, respectively). No differences were observed between the two neighborhood types in afternoon walking to neighborhood destinations.

Urban-form measures were more commonly associated with walking and bicycling than accessibility measures. Interestingly, the associations observed between urban-form measures and physical activity were not unidirectional, as urban-form measures were significantly positively related to walking and significantly negatively related to bicycling. These findings may indicate that children's walking is more common in compact urban areas, while children's bicycling is more common in sprawling urban areas. The findings regarding accessibility measures are also not unidirectional; accessibility measures were positively associated with walking to school and bicycling for leisure but negatively associated with bicycling to neighborhood destinations. These findings may indicate that children will chose to travel by bike to daily destinations only when the distances are too long to walk.

The association between "route distance to nearest park" with walking to school (positive association) and bicycling to neighborhood destination (negative association) may be attributed to the low frequency of walking to school and the high frequency of biking to neighborhood destinations in suburban neighborhoods, where parks are more accessible. Similarly, the positive association observed between "route distance to nearest store" and leisure bicycling may be attributed to the high frequency of leisure bicycling in suburban neighborhoods, where stores are less accessible.

Further bivariate analysis revealed that different psychosocial factors were associated with different types of physical activity. Regarding socio-demographic factors, age and gender were related to bicycling, which was more common among boys and among fifth graders. Likewise, the number of cars per household was negatively related to walking to school. 
Table 2: Participants' characteristics: Physical activity, psychosocial and socio-demographic characteristics

\begin{tabular}{|c|c|}
\hline Characteristics & $\mathbf{N}(\%)^{*}$ \\
\hline \multicolumn{2}{|l|}{ Physical Activity } \\
\hline Walking from home to school & $398(69.5 \%)$ \\
\hline Afternoon walking to neighborhood destinations & $313(54.9 \%)$ \\
\hline Afternoon bicycling to neighborhood destinations** & $182(35.2 \%)$ \\
\hline Afternoon bicycling for leisure** & $267(51.6 \%)$ \\
\hline \multicolumn{2}{|l|}{$\begin{array}{l}\text { Psychosocial Characteristics } \\
\text { Social factors }\end{array}$} \\
\hline Acquaintance with other children living in the neighborhood & $471(83.1 \%)$ \\
\hline Frequency of other children's outdoors play in the neighborhood & $501(88.0 \%)$ \\
\hline \multicolumn{2}{|l|}{$\begin{array}{l}\text { Inter-personal factors } \\
\text { Independent mobility }\end{array}$} \\
\hline by foot: allowed to walk in the neighborhood at daytime and in the dark & $354(62.3 \%)$ \\
\hline by bike: allowed to bike alone in the neighborhood** & $190(42.3 \%)$ \\
\hline \multicolumn{2}{|l|}{$\begin{array}{l}\text { Intra-personal factors } \\
\text { Perceived environment [M (range)] }\end{array}$} \\
\hline Neighborhood perceived as a child-friendly environment & $3.84(0-5)$ \\
\hline Perceived crime-related safety & $1.03(0-2)$ \\
\hline \multicolumn{2}{|l|}{ Travel preferences } \\
\hline Pro-walking & $246(43.5 \%)$ \\
\hline Pro-biking & $224(44.3 \%)$ \\
\hline \multicolumn{2}{|l|}{ Socio-demographic characteristics } \\
\hline \multicolumn{2}{|l|}{ Gender } \\
\hline Boy & $287(51.1 \%)$ \\
\hline Girl & $286(49.9 \%)$ \\
\hline \multicolumn{2}{|l|}{ School year } \\
\hline Grade 5 & 294 (51.3\%) \\
\hline Grade 6 & $279(48.7 \%)$ \\
\hline \multicolumn{2}{|l|}{ Bike ownership } \\
\hline Have a bicycle & $517(90.2 \%)$ \\
\hline \multicolumn{2}{|l|}{ Number of cars in household } \\
\hline 0 & $23(4.2 \%)$ \\
\hline 1 & $202(37.1 \%)$ \\
\hline $2+$ & $320(58.7 \%)$ \\
\hline
\end{tabular}

* May not add up to 573 due to missing data

** Calculated among a sub-sample of 517 children who had a bicycle 
Table 3: Bivariate logistic regression to predict walking and bicycling by environmental, social, inter- and intra-personal factors

\begin{tabular}{|c|c|c|c|c|c|c|c|c|}
\hline & \multicolumn{4}{|c|}{ Walking } & \multicolumn{4}{|c|}{ Bicycling } \\
\hline & \multicolumn{2}{|c|}{ Walking to school } & \multicolumn{2}{|c|}{$\begin{array}{l}\text { Walking to neigh- } \\
\text { borhood destinations }\end{array}$} & \multicolumn{2}{|c|}{$\begin{array}{l}\text { Bicycling to neigh- } \\
\text { borhood destinations }\end{array}$} & \multicolumn{2}{|c|}{ Leisure bicycling } \\
\hline & $\begin{array}{c}\text { OR } \\
(95 \% \mathrm{CI})\end{array}$ & $\mathbf{N}$ & $\begin{array}{c}\text { OR } \\
(95 \% \mathrm{CI})\end{array}$ & $\mathbf{N}$ & $\begin{array}{c}\text { OR } \\
(95 \% \mathrm{CI})\end{array}$ & $\mathbf{N}$ & $\begin{array}{c}\text { OR } \\
(95 \% \mathrm{CI})\end{array}$ & $\mathbf{N}$ \\
\hline \multicolumn{9}{|l|}{ Neighborhood Type } \\
\hline Suburban (ref. traditional) & $\begin{array}{c}0.34^{* * *} \\
(0.24-0.50)\end{array}$ & 573 & $\begin{array}{c}1.32 \\
(0.95-1.83)\end{array}$ & 570 & $\begin{array}{c}0.50^{* * *} \\
(0.34-0.71)\end{array}$ & 510 & $\begin{array}{c}0.49^{* * *} \\
(0.35-0.69)\end{array}$ & 510 \\
\hline \multicolumn{9}{|c|}{ Urban form measures (ref. low) } \\
\hline $\begin{array}{l}\text { Street connectivity } \\
\text { (intersections/sq km) }\end{array}$ & $\begin{array}{c}1.77^{* *} \\
(1.16-2.71)\end{array}$ & 547 & $\begin{array}{c}1.11 \\
(0.75-1.63)\end{array}$ & 570 & $\begin{array}{c}0.69 \\
(0.45-1.05)\end{array}$ & 510 & $\begin{array}{c}0.76 \\
(0.50-1.15)\end{array}$ & 508 \\
\hline $\begin{array}{l}\text { Residential density } \\
\text { (households/sq km) }\end{array}$ & $\begin{array}{c}2.25^{* * *} \\
(1.60-3.75)\end{array}$ & 547 & $\begin{array}{c}1.35 \\
(0.93-1.97)\end{array}$ & 570 & $\begin{array}{c}0.35^{* * *} \\
(0.33-0.55)\end{array}$ & 510 & $\begin{array}{c}0.37^{* * *} \\
(0.24-0.56)\end{array}$ & 508 \\
\hline $\begin{array}{l}\text { Built coverage } \\
\text { (built cover/built lots) }\end{array}$ & $\begin{array}{c}2.64^{* *} \\
(1.48-4.71)\end{array}$ & 547 & $\begin{array}{c}1.24^{*} \\
(1.05-1.46)\end{array}$ & 570 & $\begin{array}{c}0.78 \\
(0.44-1.39)\end{array}$ & 510 & $\begin{array}{c}0.53^{*} \\
(0.30-0.92)\end{array}$ & 508 \\
\hline \multicolumn{9}{|l|}{ Land use measures (ref. low) } \\
\hline $\begin{array}{l}\text { Route distance to nearest } \\
\text { store }\end{array}$ & $\begin{array}{c}0.90 \\
(0.77-1.06)\end{array}$ & 558 & $\begin{array}{c}0.99 \\
(0.87-1.13) \\
\end{array}$ & 555 & $\begin{array}{c}1.46^{* * *} \\
(1.24-1.73)\end{array}$ & 497 & $\begin{array}{c}1.38^{*} \\
(1.03-1.85)\end{array}$ & 502 \\
\hline $\begin{array}{l}\text { Route distance to nearest } \\
\text { park }\end{array}$ & $\begin{array}{c}1.43^{* * *} \\
(1.19-1.72)\end{array}$ & 556 & $\begin{array}{c}1.15 \\
(0.96-1.37) \\
\end{array}$ & 548 & $\begin{array}{c}0.43^{* *} \\
(0.270 .69)\end{array}$ & 485 & $\begin{array}{c}0.79^{*} \\
(0.66-0.96)\end{array}$ & 491 \\
\hline Route distance to school & $\begin{array}{c}0.13^{* * *} \\
(0.08-0.20)\end{array}$ & 541 & $\begin{array}{c}0.64 \\
(0.37-1.09) \\
\end{array}$ & 563 & $\begin{array}{c}0.96 \\
(0.56-1.65)\end{array}$ & 508 & $\begin{array}{c}0.99 \\
(0.59-1.66)\end{array}$ & 506 \\
\hline $\begin{array}{l}\text { I know many children } \\
\text { who live in my neighbor- } \\
\text { hood (ref. disagree) }\end{array}$ & $\begin{array}{c}1.91^{*} \\
(1.20-3.04)\end{array}$ & 541 & $\begin{array}{c}1.42 \\
(0.91-2.20)\end{array}$ & 564 & $\begin{array}{c}1.35 \\
(0.79-2.31)\end{array}$ & 505 & $\begin{array}{c}1.21 \\
(0.74-1.98)\end{array}$ & 503 \\
\hline $\begin{array}{l}\text { In my neighborhood } \\
\text { many children can be } \\
\text { seen playing outside (ref. } \\
\text { disagree) }\end{array}$ & $\begin{array}{c}1.21(0.71- \\
2.07)\end{array}$ & 569 & $\begin{array}{c}1.83^{* *}(1.09 \\
-3.06)\end{array}$ & 566 & $\begin{array}{c}0,99(0.56 \\
-1.77)\end{array}$ & 506 & $\begin{array}{c}1.16(0.66 \\
-2.03)\end{array}$ & 504 \\
\hline
\end{tabular}

Numbers in bold represent significant associations: ${ }^{*} \mathrm{p}<0.01{ }^{* *} \mathrm{p}<0.001 ;{ }^{* * *} \mathrm{p}<0.0001$

Multivariate logistic regression analysis was used to identify environmental correlates of physical activity, while controlling for social, inter-, and intra-personal factors (table 4). Given the correlations between several built environmental measures, the strongest significant predictors in the bivariate analysis were included in the multivariate models, consisting of one urban form and one accessibility measure. Overall, after controlling for social, intra-, and inter-personal factors, built environmental attributes remained strong and significant predictors of walking (to school and to neighborhood destinations) and bicycling (to neighborhood destinations and for leisure). In most cases, urban-form measures were stronger predictors than accessibility measures. 
Table 3: Bivariate logistic regression to predict walking and bicycling by environmental, social, inter- and intra-personal factors (continued)

\begin{tabular}{|c|c|c|c|c|c|c|c|c|}
\hline & \multicolumn{4}{|c|}{ Walking } & \multicolumn{4}{|c|}{ Bicycling } \\
\hline & \multicolumn{2}{|c|}{ Walking to school } & \multicolumn{2}{|c|}{$\begin{array}{c}\text { Walking to neighbor- } \\
\text { hood destinations }\end{array}$} & \multicolumn{2}{|c|}{$\begin{array}{l}\text { Bicycling to neigh- } \\
\text { borhood destinations }\end{array}$} & \multicolumn{2}{|c|}{ Leisure bicycling } \\
\hline & $\begin{array}{c}\text { OR } \\
(95 \% \mathrm{CI}) \\
\end{array}$ & $\mathbf{N}$ & $\begin{array}{c}\text { OR } \\
(95 \% \mathrm{CI}) \\
\end{array}$ & $\mathbf{N}$ & $\begin{array}{c}\text { OR } \\
(95 \% \mathrm{CI}) \\
\end{array}$ & $\mathbf{N}$ & $\begin{array}{c}\text { OR } \\
(95 \% \mathrm{CI})\end{array}$ & $\mathbf{N}$ \\
\hline \multicolumn{9}{|c|}{ Independent mobility (ref. low) } \\
\hline $\begin{array}{l}\text { High independent } \\
\text { mobility by foot }\end{array}$ & $\begin{array}{c}1.19(0.83- \\
1.72)\end{array}$ & 544 & $\begin{array}{c}1.89^{* *}(1.34 \\
-2.67)\end{array}$ & 565 & $\begin{array}{c}2.11^{* * *} \\
(1.42-3.13)\end{array}$ & 505 & $\begin{array}{c}1.86^{* *} \\
(1.29-2.68)\end{array}$ & 503 \\
\hline $\begin{array}{l}\text { High independent } \\
\text { mobility by bike* }\end{array}$ & $\begin{array}{c}1.18 \\
(0.79-1.77)\end{array}$ & 449 & $\begin{array}{c}1.44 \\
(0.98-2.10)\end{array}$ & 498 & $\begin{array}{c}3.64^{* * *} \\
(2.39-5.55)\end{array}$ & 435 & $\begin{array}{c}3.85^{* * *} \\
(2.57-5.78)\end{array}$ & 493 \\
\hline \multicolumn{9}{|c|}{ Perceived environment (ref. low) } \\
\hline $\begin{array}{l}\text { Neighborhood perceived } \\
\text { as a child-friendly } \\
\text { environment }\end{array}$ & $\begin{array}{c}1.10 \\
(0.95-1.27)\end{array}$ & 544 & $\begin{array}{c}1.10 \\
(0.96-1.26)\end{array}$ & 559 & $\begin{array}{c}1.25^{* *} \\
(1.06-1.48)\end{array}$ & 500 & $\begin{array}{c}1.34^{* * *} \\
(1.15-1.56)\end{array}$ & 498 \\
\hline $\begin{array}{l}\text { Perceived crime-related } \\
\text { safety }\end{array}$ & $\begin{array}{c}1.21 \\
(0.94-1.56) \\
\end{array}$ & 544 & $\begin{array}{c}1.54^{* * *} \\
(1.21-1.96) \\
\end{array}$ & 560 & $\begin{array}{c}1.61^{* *} \\
(1.23-2.10)\end{array}$ & 500 & $\begin{array}{c}1.63^{* * *} \\
(1.26-2.11)\end{array}$ & 493 \\
\hline \multicolumn{9}{|l|}{ Travel preferences (ref. not) } \\
\hline pro-walking & $\begin{array}{c}2.35^{* * *} \\
(1.59-3.46) \\
\end{array}$ & 539 & $\begin{array}{c}1.27 \\
(0.91-1.78) \\
\end{array}$ & 562 & $\begin{array}{c}1.10 \\
(0.76-1.59) \\
\end{array}$ & 505 & $\begin{array}{c}1.14 \\
(0.80-1.63) \\
\end{array}$ & 502 \\
\hline pro-biking & $\begin{array}{c}1.74^{*} \\
(1.17-2.56) \\
\end{array}$ & 506 & $\begin{array}{c}1.46^{*} \\
(1.03-2.09) \\
\end{array}$ & 503 & $\begin{array}{c}2.66^{* * *} \\
(1.82-3.87)\end{array}$ & 493 & $\begin{array}{c}2.47^{* * *} \\
(1.71-3.57)\end{array}$ & 493 \\
\hline \multicolumn{9}{|c|}{ Socio-demographic characteristics } \\
\hline \multicolumn{9}{|l|}{ Gender } \\
\hline Girl (ref.) & 1 & 544 & 1 & 573 & 1 & 510 & 1 & 508 \\
\hline Boy & $\begin{array}{c}0.93 \\
(0.65-1.32) \\
\end{array}$ & 544 & $\begin{array}{c}1.29 \\
(0.93-1.79) \\
\end{array}$ & 573 & $\begin{array}{c}2.14^{* * *} \\
(1.47-3.10)\end{array}$ & 510 & $\begin{array}{c}2.14^{* * *} \\
(1.50-3.05)\end{array}$ & 508 \\
\hline \multicolumn{9}{|l|}{ School year } \\
\hline Grade 5 (ref.) & 1 & 544 & 1 & 573 & 1 & 510 & 1 & 508 \\
\hline Grade 6 & $\begin{array}{c}0.97 \\
(0.68-1.39)\end{array}$ & 544 & $\begin{array}{c}1.36 \\
(0.98-1.90)\end{array}$ & 573 & $\begin{array}{c}0.62^{* *} \\
(0.43-0.89)\end{array}$ & 510 & $\begin{array}{c}0.61^{* *} \\
(0.43-0.87)\end{array}$ & 508 \\
\hline \multicolumn{9}{|c|}{ Number of cars in household } \\
\hline 0 (ref.) & 1 & 544 & 1 & 567 & 1 & 508 & 1 & 508 \\
\hline 1 & $\begin{array}{c}0.12^{*} \\
(0.02-0.90) \\
\end{array}$ & 544 & $\begin{array}{c}0.46 \\
(0.18-1.23) \\
\end{array}$ & 567 & $\begin{array}{c}0.35 \\
(0.12-1.03) \\
\end{array}$ & 508 & $\begin{array}{c}0.71 \\
(0.24-2.07)\end{array}$ & 508 \\
\hline $2+$ & $\begin{array}{c}0.09^{*} \\
(0.01-0.70)\end{array}$ & 544 & $\begin{array}{c}0.43 \\
(0.17-1.14)\end{array}$ & 567 & $\begin{array}{c}0.37 \\
(0.13-1.06)\end{array}$ & 508 & $\begin{array}{c}0.75 \\
(0.26-2.15)\end{array}$ & 508 \\
\hline
\end{tabular}

Numbers in bold represent significant associations: ${ }^{*} \mathrm{p}<0.01 ;{ }^{* *} \mathrm{p}<0.001 ;{ }^{* * *} \mathrm{p}<0.0001$ 
The strongest predictor of walking to school was having a short (vs. long) route distance to school $(\mathrm{OR}=0.12, \mathrm{CI}=0.07-0.20)$, followed by living in an area with high (vs low) built coverage $(\mathrm{OR}=2.57$, $\mathrm{CI}=1.29-5.10)$, knowing other children in the neighborhood ( $\mathrm{OR}=2.10, \mathrm{CI}=1.20-3.67)$, being a prowalking type $(\mathrm{OR}=1.82, \mathrm{CI}=1.16-2.85)$, and having more than one car per household $(\mathrm{OR}=0.63$, $\mathrm{CI}=0.40-0.97)$.

The strongest predictor of walking to neighborhood destinations was living in an area with high (vs low) built coverage $(\mathrm{OR}=2.21, \mathrm{CI}=1.24-3.94)$, followed by living in an area where many children can be seen playing outdoors $(\mathrm{OR}=1.88, \mathrm{CI}=1.08-3.25)$, having high independent mobility (by foot) $(\mathrm{OR}=1.71, \mathrm{CI}=1.17-2.51)$, and perceiving the neighborhood environment as safe (in terms of crime) $(\mathrm{OR}=1.39, \mathrm{CI}=1.07-1.81)$.

The strongest predictors of bicycling to neighborhood destinations were having high independent mobility (by bike) $(\mathrm{OR}=2.73, \mathrm{CI}=1.68-4.44)$ and being in fifth grade (vs sixth grade) $(\mathrm{OR}=0.41$, $\mathrm{CI}=0.25-0.66)$. Other significant predictors included being a pro-biking type $(\mathrm{OR}=1.97, \mathrm{CI}=1.23-3.14)$, being a boy $(\mathrm{OR}=1.66, \mathrm{CI}=1.01-2.72)$, and living in an area with low residential density $(\mathrm{OR}=0.37$, $\mathrm{CI}=0.20=0.69)$.

The strongest predictors of bicycling for leisure were having high independent mobility (by bike) $(\mathrm{OR}=3.06, \mathrm{CI}=1.92-4.90)$ and living in an area with low residential density $(\mathrm{OR}=0.36, \mathrm{CI}=0.18-0.71)$. Other significant predictors included being in fifth grade (vs sixth grade) $(\mathrm{OR}=0.54, \mathrm{CI}=0.35-0.85)$ and being a pro-biking type $(\mathrm{OR}=1.73, \mathrm{CI}=1.09-2.74)$.

\section{Discussion}

The present study assessed associations between built environment variables and physical activity among children in an urban setting in Israel. While many previous studies used aggregate measures of physical activity (e.g., overall physical activity, active travel), little is known about the contribution of specific environmental attributes to specific types of physical activity. The current study addressed this gap by examining four different kinds of physical activity, varying by type and purpose including walking to school, walking to neighborhood destinations, bicycling to neighborhood destinations, and bicycling for leisure. Our findings show that different attributes in the built environment are associated with walking and bicycling for different purposes. In most cases, walking and bicycling were associated with urban-form measures (density, street connectivity, and built coverage), but not with accessibility measures (route distances to neighborhood destinations).

Overall, the levels of walking and bicycling for all purposes reported in our study are quite high relative to those reported in previous studies (Kerr et al. 2006; McDonald 2007; Zhu and Lee 2009). This may be attributed to socio-cultural aspects on the one hand or to environmental conditions on the other (given the relatively high population density in the city of Rishon-Lezion, 4012/square kilometer, which makes it convenient to walk and bicycle for daily routine purposes).

The associations between urban-form measures and children's walking and bicycling were found to be in opposite directions: walking (to school and to neighborhood destinations) was more common in compact urban areas, while bicycling (for travel and leisure) was more common in sprawling urban areas. These findings are in line with a previous study conducted in Toronto (Van Vliet 1983). Van Vliet found that compared to city children, suburban children walked less and bicycled more to various destinations (e.g., library, movie, restaurant, and playground).

At first sight, our findings regarding children's walking and bicycling may be explained by travel distances, which are likely to be longer in suburban neighborhoods and thus make walking less convenient. However, this explanation is not fully supported by our empirical findings regarding travel distances in the study area. In traditional neighborhoods, route distances to stores were indeed shorter, but route dis- 
Table 4: Multivariate logistic regression to predict walking and bicycling by environmental, social, inter- and intra-personal factors

\begin{tabular}{|c|c|c|c|c|c|c|c|c|c|}
\hline & \multicolumn{4}{|c|}{ Walking } & \multicolumn{4}{|c|}{ Bicycling } \\
\hline & & \multicolumn{2}{|c|}{ Walking to school } & \multicolumn{2}{|c|}{$\begin{array}{c}\text { Walking to neighbor- } \\
\text { hood destinations }\end{array}$} & \multicolumn{2}{|c|}{$\begin{array}{l}\text { Bicycling to neighbor- } \\
\text { hood destinations }\end{array}$} & \multicolumn{2}{|c|}{ Leisure bicycling } \\
\hline & & $\begin{array}{c}\text { OR } \\
(95 \% \mathrm{CI}) \\
\end{array}$ & $\begin{array}{c}\text { Estimate } \\
(\mathrm{SE})\end{array}$ & $\begin{array}{c}\text { OR } \\
(95 \% \mathrm{CI}) \\
\end{array}$ & $\begin{array}{c}\text { Estimate } \\
\text { (SE) }\end{array}$ & $\begin{array}{c}\text { OR } \\
(95 \% \mathrm{CI}) \\
\end{array}$ & \begin{tabular}{|c|} 
Estimate \\
$(\mathrm{SE})$
\end{tabular} & $\begin{array}{c}\text { OR } \\
(95 \% \mathrm{CI}) \\
\end{array}$ & $\begin{array}{c}\text { Estimate } \\
\text { (SE) }\end{array}$ \\
\hline \multirow{7}{*}{$\begin{array}{l}\text { Environmental } \\
\text { factors }\end{array}$} & \multicolumn{9}{|c|}{ Urban form measures (ref. low) } \\
\hline & $\begin{array}{l}\text { Residential Density } \\
\text { (household/sq km) }\end{array}$ & NI & NI & NI & NI & $\begin{array}{c}0.48^{* *} \\
(0.20-0.69)\end{array}$ & $\begin{array}{r}-0.72^{*} \\
(0.13)\end{array}$ & $\begin{array}{c}0.36^{* *} \\
(0.18-0.71)\end{array}$ & $\begin{array}{c}-1.02^{* *} \\
(0.35)\end{array}$ \\
\hline & $\begin{array}{l}\text { Built Coverage (built } \\
\text { cover/built lots) }\end{array}$ & $\begin{array}{c}2.57^{* *} \\
(1.29-5.10) \\
\end{array}$ & $\begin{array}{r}0.94^{* *} \\
(0.35) \\
\end{array}$ & $\begin{array}{c}2.21^{* *} \\
(1.24-3.94) \\
\end{array}$ & $\begin{array}{r}0.79^{* *} \\
(0.29) \\
\end{array}$ & NI & NI & NI & NI \\
\hline & \multicolumn{9}{|c|}{ Land use accessibility measures (ref. low) } \\
\hline & \begin{tabular}{|l|}
$\begin{array}{l}\text { Route Distance to } \\
\text { nearest store }\end{array}$ \\
\end{tabular} & NI & NI & $\begin{array}{c}0.98 \\
(0.86-1.13) \\
\end{array}$ & $\begin{array}{l}-0.02 \\
(0.07) \\
\end{array}$ & $\begin{array}{c}1.81 \\
(0.96-1.45) \\
\end{array}$ & $\begin{array}{l}-0.99 \\
(0.32) \\
\end{array}$ & NI & NI \\
\hline & $\begin{array}{l}\text { Route distance to } \\
\text { nearest park }\end{array}$ & NI & NI & NI & NI & NI & NI & $\begin{array}{c}1.11 \\
(0.84-1.45)\end{array}$ & $\begin{array}{c}0.10 \\
(0.14)\end{array}$ \\
\hline & $\begin{array}{l}\text { Route distance to } \\
\text { school }\end{array}$ & $\begin{array}{c}0.12^{* * *} \\
(0.07-0.20)\end{array}$ & $\begin{array}{l}-2.11 \\
(0.26)\end{array}$ & NI & NI & NI & NI & NI & NI \\
\hline \multirow[b]{2}{*}{ Social factors } & $\begin{array}{l}\text { I know many chil- } \\
\text { dren who live in my } \\
\text { neighborhood } \\
\end{array}$ & $\begin{array}{c}2.10^{* *} \\
(1.20-3.67)\end{array}$ & $\begin{array}{c}0.74 \\
(0.29)\end{array}$ & NI & NI & NI & NI & $\mathrm{NI}$ & NI \\
\hline & $\begin{array}{l}\text { In my neighbor- } \\
\text { hood many children } \\
\text { can be seen playing } \\
\text { outside }\end{array}$ & NI & NI & $\begin{array}{c}1.88^{*} \\
(1.08-3.25)\end{array}$ & $\begin{array}{l}0.63^{*} \\
(0.28)\end{array}$ & NI & NI & NI & NI \\
\hline
\end{tabular}

Numbers in bold represent significant associations: ${ }^{*} \mathrm{p}<0.01 ;{ }^{* *} \mathrm{p}<0.001 ;{ }^{* * *} \mathrm{p}<0.0001$

$\mathrm{NI}=$ Not Included

tances to parks were longer, and no significant differences were observed between the two neighborhood types in the route distances to school (Table 1).

Following this, our findings regarding urban form and walking and bicycling may be explained by the differences between pedestrians and bicyclers in terms of their environmental needs: Pedestrians move relatively slow in space, while being open to absorb impressions from the environment. Therefore, they are likely to prefer diverse and complex environments, including multiple buildings of various types and diverse urban design elements (e.g., trees, benches, billboards). Such environments are typical to compact urban areas, such as traditional neighborhoods. On the other hand, bicyclists move relatively fast in space, while needing to focus on the route and maneuver through traffic. Therefore, bicyclists are likely to prefer simple and spacious environments with minimal distractions, including long horizons. Such environments are typical to sprawling urban forms found in the suburban neighborhoods (Frank, Engelke, and Schmidt 2003). It may be interesting for future research to explore children's environmental needs for walking and bicycling by using qualitative methods (e.g., go-along interviews, cognitive mapping, etc.). On a practical level, the gap in environmental correlates of walking and bicycling indicates that certain environments may encourage children's walking and hinder their bicycling at the same time (and vice versa), and therefore raises the need for a more clear distinction between children-related walkability and bikeablilty. 
Table 4: Multivariate logistic regression to predict walking and bicycling by environmental, social, inter- and intra-personal factors (continued)

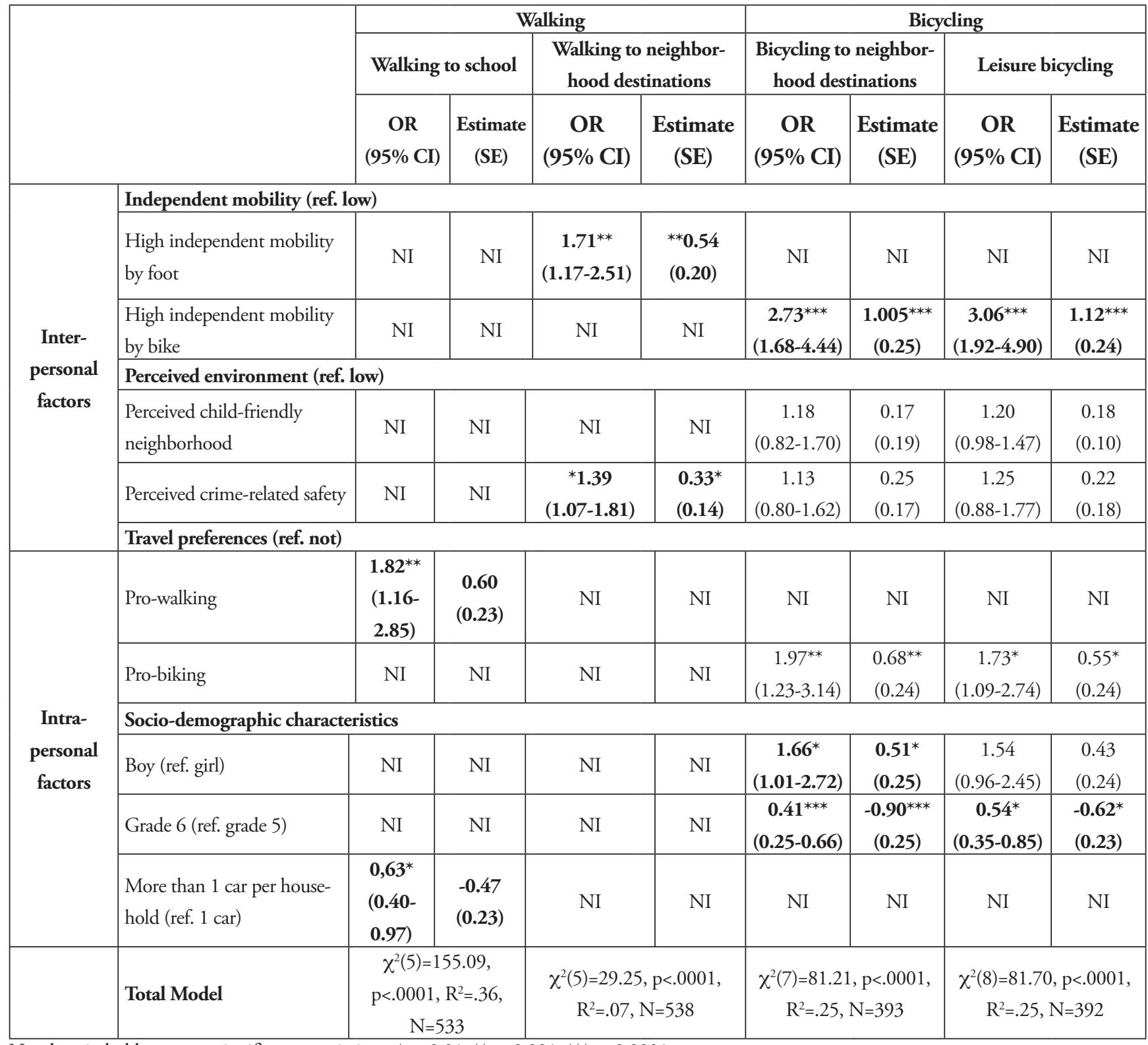

Numbers in bold represent significant associations: ${ }^{*} \mathrm{p}<0.01 ;{ }^{* *} \mathrm{p}<0.001 ;{ }^{* * *} \mathrm{p}<0.0001$

$\mathrm{NI}=$ Not Included

The positive associations observed in this study between urban-form measures and children's walking to school are in line with another recent study that was conducted recently in Israel (Omer et al. 2012), which identified positive associations between street connectivity and pedestrian flow, especially among children. Moreover, as found in our study, Omer et al. found that street connectivity was more strongly related to pedestrian flow than land-use measures. Contrary to our findings, recent studies have reported an opposite association between street connectivity and walking (e.g., Panter et al. 2010), while hypothesizing that higher connectivity may relate to busier streets and hence may be a barrier to walking. However, this is less likely to be the case in our study area given that no differences were observed 
in traffic flow between the highly connected areas (traditional neighborhoods) and the cul-de-sac areas (suburban neighborhoods) (PGL 2010). Moreover, it is not likely that pedestrian exposure to traffic would be a barrier to walking in highly connected areas in our study since no differences were observed between traditional and suburban neighborhoods in terms of children's perceived road safety, which was also reported in the survey and presented elsewhere (Moran 2013).

The negative associations observed in this study between children's bicycling and urban-form measures (residential density, built coverage) may be attributed to the compact urban form in the study area (the city of Rishon LeZion), which makes it bikeable even in low density parts of the city, as these are relatively interconnected and hence provide fair accessibility for bicyclists. Following this it may be hypothesized that bicycling is likely to be inversely correlated with urban-form attributes (e.g., density, street connectivity) as long as the overall urban form is compact. And indeed, this assumption is supported by empirical literature suggesting that bicycling is negatively associated with urban-form measures (e.g., density, street connectivity) in high density cities [e.g., a study conducted in Izegem, Belgium (population density 1100/kilometers ${ }^{2}$ ) (Van Dyck et al. 2009)] but positively associated low-density cities (e.g., a study conducted in Perth, Australia (population density 286/kilometers ${ }^{2}$ ) (Trapp et al. 2011)].

The negative associations observed in this study between children's bicycling and urban-form measures highlight the gap in environmental needs between children and adults. While previous studies indicate that adults' physical activity is more common in compact urban areas (Badland and Schofield 2005; Humpel, Owen, and Leslie 2002), our findings along with other recent studies (e.g., Laxer and Janssen 2013; Mecredy, Pickett, and Janssen 2011; Van Dyck et al. 2009) show that children and adolescents are less active in such environments. This gap might be attributed to the different types of physical activity that adults and children usually perform. While adults are more likely to perform utilitarian walking for errands etc., children and adolescents might be more likely to perform leisure activities in their daily routine. Future studies should address this issue by distinguishing between different types of physical activity (walking, bicycling, for travel and/or leisure) among children and adults living in the same environments.

In addition to environmental measures, several psychosocial and socio-demographic factors were found related to children's physical activity. These findings stand in line with ecological models (Edwards and Tsouros 2006; McLeroy et al. 1988; Sallis and Owen 1990; Sallis 2008; Stokols 1992). The positive association observed in our study between children's independent mobility and bicycling are in line with previous studies (Page et al. 2010; Wen et al. 2009). Similarly, previous studies support our findings regarding the associations between children's walking and social aspects, such as acquaintance with other neighbors or nearby children and other children's outdoors play (Timperio et al. 2006; Veitch, Salmon, and Ball 2010). These positive associations can be explained by a higher sense of security that is related to these social community aspects. This assumption may be explored in future analysis. Perceptions regarding the neighborhood environment were found to be related to walking and bicycling. According to the ecological framework, the objective built environment may affect perceptions, which, in turn, may influence behavior (McMillan 2005; Mitra 2013). Therefore, future analysis may benefit from examining the mediating role of such perceptions in the associations between the objective built environment and walking and bicycling.

Bicycling was more common among boys, as observed in previous studies suggesting that boys engage in more physical activity of various kinds compared to girls (e.g., walking, bicycling, outdoors play) (Sallis, Prochaska and Taylor 2000). Similarly, empirical literature indicates that boys have more spatial freedom to be physically active outdoors (Kyttä 2002; Mackett et al. 2007; Page et al. 2010; Valentine and McKendrck 1997). And indeed, additional analysis of this study (presented elsewhere, Moran 2013) showed that independent mobility was higher among boys compared to girls. Extensive literature 
suggests that limited independent mobility may affect mobility choices in childhood (e.g., Valentine and McKendrck 1997; Valentine 1997). Therefore future analysis should explore the potential mediating role of independent mobility on the observed relationship between gender and bicycling. Furthermore, future research may benefit from exploring the potential moderating/mediating role of independent mobility on the relationships between the environmental attributes and walking and bicycling among boys and girls.

To our knowledge, this is the first study in Israel to examine associations between objectively measured environmental attributes and self-reported physical activity. The integration between GIS and selfreported data provides a deep and comprehensive understanding of this environment-behavior nexus. A primary strength of the current study lies in our attempt to match specific environmental measures with different types of travel-related physical activity. This issue is particularly important as it addresses a gap in the literature since many of the studies to date focused on more general outcome measures without distinguishing between walking and bicycling for different purposes.

Some limitations of this study should be acknowledged. First, the study design is cross-sectional and hence causality cannot be assumed. Second, the survey method is biased to memory limitations and social desirability. Another limitation is due to the route measures used in our study that were based on the shortest-path approach, which might not fully represent actual routes used by children (Buliung et al. 2013). Finally, the generalizability of the findings is limited given its setting —one city in Israel—and the narrow age range of the study population - fifth and sixth graders. However, these choices of study area and population aimed to ensure diverse environments and a homogenous population, which help examine the associations between the built environment and physical activity with minimum intervening factors.

\section{Conclusions}

In summary, urban-form measures were found to have stronger influence on children's physical activity than did accessibility measures. Children's walking was associated with compact urban form, while children's bicycling was associated with sprawling urban form. These findings suggest that certain environments may encourage children's walking and hinder their bicycling at the same time (and vice versa), and therefore raise the need for a more clear distinction between children-related walkability and bikeablilty. From a methodological perspective, future studies may benefit from examining different types of physical activity separately, instead of examining overall physical activity or overall walking and bicycling, as has been done in many studies to date. In addition to environmental factors, several psychosocial variables were found related to children's physical activity, such as social factors and independent mobility of children. These findings support the ecological model as a theoretical framework for research on the built environment and physical activity. On a practical level, these findings imply that along with urban planning practice, enhancing psychosocial factors may help promote children's physical activity.

\section{References}

Audirac, I., and A. H. Shermyen 1994. An evaluation of neotraditional design's social prescription: Postmodern placebo or remedy for suburban malaise? Journal of Planning Education and Research 13(3): 161-173.

Badland, H., and G. Schofield. 2005. Transport, urban design, and physical activity: An evidence-based update. Transportation Research D 10(3): 177-196.

Boarnet, M. G., C. L. Anderson, K. Day, T. McMillan, and M. Alfonzo. 2005. Evaluation of the California Safe Routes to School legislation: Urban form changes and children's active transportation to 
school. American Journal of Preventive Medicine 28(2): 134-140.

Buliung, R. N., K. Larsen, G. E. Faulkner, and M. R. Stone. 2013. The "path" not taken: Exploring structural differences in mapped- versus shortest-network-path school travel routes. American Journal of Public Health 103(9): 1589־1596.

Brage, S., N. Wedderkopp, U. Ekelund, P. W. Franks, N. J. Wareham, L. B. Andersen, and K. Froberg. 2004. Features of the metabolic syndrome are associated with objectively measured physical activity and fitness in Danish children, the European Youth Heart Study (EYHS). Diabetes Care 27(9): 2141-2148.

Braza, M., W. Shoemaker, and A. Seeley. 2004. Neighborhood design and rates of walking and biking to elementary school in 34 California communities. American Journal of Health Promotion 19(2): $128-136$.

Calthorpe, P. 1993. The Next American Metropolis: Ecology, Community, and The American Dream. New York: Princeton Architectural Press.

Carver, A., J. Salmon, K. Campbell, L. Baur, S. Garnett, and D. Crawford. 2005. How do perceptions of local neighborhood relate to adolescents' walking and cycling? American Journal of Health Promotion 20(2): 139-147.

Cerin, E., E. Leslie, L. D. Toit, N. Owen, and L. D. Frank. 2007. Destinations that matter: Associations with walking for transport. Health and Place 13(3): 713-724.

Cervero, R. 1998. The Transit Metropolis: A Global Inquiry. Washington, DC: Island Press.

Davison, K. K., and C. T. Lawson. 2006. Do attributes in the physical environment influence children's physical activity? A review of the literature. International Journal of Behavioral Nutrition and Physical Activity 3(1): 19.

De Meester, F., D. Van Dyck, I. De Bourdeaudhuij, B. Deforche, J. F. Sallis, and G. Cardon. 2012. Active living neighborhoods: Is neighborhood walkability a key element for Belgian adolescents? $B M C$ Public Health 12(1): 7.

De Vries, S. I., M. Hopman-Rock, I. Bakker, R. A. Hirasing, and W. Van Mechelen. 2010. Built environmental correlates of walking and cycling in Dutch urban children: Results from the SPACE study. International Journal of Environmental Research and Public Health 7(5): 2309-2324.

Dill, J. 2009. Bicycling for transportation and health: The role of infrastructure. Journal of Public Health Policy 30(S1): S95-S110.

Duany, A., and E. Plater-Zyberk. 1992. The second coming of the American small town. Wilson Quarterly 16(1): 3-51.

Ducheyne, F., I. De Bourdeaudhuij, M. Lenoir, H. Spittaels, and G. Cardon. 2013. Children's cycling skills: Development of a test and determination of individual and environmental correlates. Accident Analysis and Prevention 50: 688-97.

Edwards, P., and A. D. Tsouros. 2006. Promoting Physical Activity and Active Living in Urban Environments. The Role of Local Governments. Geneva: World Health Organization.

Edwards, P. and A. D. Tsouros. 2008. A Healthy City is an Active City: A Physical Activity Planning Guide. Geneva: World Health Organization, Regional Office for Europe.

Ekelund, U., S. Anderssen, K. Froberg, L. B. Sardinha, L. B. Andersen, and S. Brage. 2007. Independent associations of physical activity and cardiorespiratory fitness with metabolic risk factors in children: The European Youth Heart Study. Diabetologia 50(9): 1832-1840.

Ekelund, U., S. Brage, K. Froberg, M. Harro, S. A. Anderssen, L. B. Sardinha, C. Riddoch, and L. B. Andersen. 2006. TV viewing and physical activity are independently associated with metabolic risk in children: The European Youth Heart Study. PLoS Medicine 3(12): e488.

Ewing, R., W. Schroeer, and W. Greene. 2004. School location and student travel analysis of factors af- 
fecting mode choice. Transportation Research Record 1895(1): 55-63.

Ferreira, I., K. Van Der Horst, W. Wendel-Vos, S. Kremers, F. Van Lenthe, and J. Brug. 2007. Environmental correlates of physical activity in youth-a review and update. Obesity Reviews 8(2): 129-154.

Frank, L., P. Engelke, and T. Schmid. 2003. Health and Community Design: The Impact of the Built Environment on Physical Activity. Washington, DC: Island Press.

Frank, L. D., J. F. Sallis, B. E. Saelens, L. Leary, K. Cain, T. L. Conway, and P. M. Hess. 2010. The development of a walkability index: Application to the Neighborhood Quality of Life Study. British Journal of Sports Medicine 44(13): 924-933.

Frumkin, H., L. Frank, and R. J. Jackson. 2004. Urban Sprawl and Public Health: Designing, Planning, and Building for Healthy Communities. Washington, DC: Island Press.

Gil, T., and S. Handy. 2008. Children's biking for non-school purposes: Getting to soccer games in Davis, California. Transportation Research Record 2074(1): 40-45.

Handy, S. 2004. Community design and physical activity: What do we know? And what don't we know? National Institute of Environmental Health Sciences Conference Obesity and the Built Environment: Improving Public Health through Community Design, May 24-26, 2004, Washington DC.

Heath, G. W., R. C. Brownson, J. Kruger, R. Miles, K. E. Powell, and L. T. Ramsey. 2006. The effectiveness of urban design and land use and transport policies and practices to increase physical activity: A systematic review. Journal of Physical Activity and Health 3: S55.

Holt, N., J. Spence, Z. Sehn, and N. Cutumisu. 2008. Neighborhood and developmental differences in children's perceptions of opportunities for play and physical activity. Health and Place 14(1): 2-14.

Humpel, N., N. Owen, and E. Leslie. 2002. Environmental factors associated with adults' participation in physical activity: A review. American Journal of Preventive Medicine 22(3): 188-199.

Israeli Education Law. 1959. School registration regulations, paragraph $7 \mathrm{~b}$.

Kerr, J., D. Rosenberg, J. F. Sallis, B. E. Saelens, L. D. Frank, and T. L. Conway. 2006. Active commuting to school: Associations with environment and parental concerns. Medicine and Science in Sports and Exercise 38(4): 787.

Kyttä, M. 2002. Affordances of children's environments in the context of cities, small towns, suburbs and rural villages in Finland and Belarus. Journal of Environmental Psychology 22(1): 109-123.

Larsen, K., J. Gilliland, P. Hess, P. Tucker, J. Irwin, and M. He. 2009. The influence of the physical environment and socio-demographic characteristics on children's mode of travel to and from school. American Journal of Public Health 99(3): 520.

Laxer, R. E., and I. Janssen. 2013. The proportion of youths' physical inactivity attributable to neighborhood built environment features. International Journal of Health Geographies 12(1): 31.

Lee, C. and A. V. Moudon. 2006. The 3Ds R: Quantifying land use and urban form correlates of walking. Transportation Research D 11(3): 204-215.

Leslie, E., N. Coffee, L. Frank, N. Owen, A. Bauman, and G. Hugo. 2007. Walkability of local communities: Using Geographic Information Systems (GIS) to objectively assess relevant environmental attributes. Health and Place 13: 111-122.

Mackett, R., B. Brown, Y. Gong, K. Kitazawa, and J. Paskins. 2007. Children's independent movement in the local environment. Built Environment 33(4): 454-468.

Manaugh, K., and A. El-Geneidy. 2011. Validating walkability indices: How do different households respond to the walkability of their neighborhood? Transportation Research D 16(4): 309-315.

McConville, M. E., D. A. Rodríguez, K. Clifton, G. Cho, and S. Fleischhacker. 2011. Disaggregate land uses and walking. American Journal of Preventive Medicine 40(1): 25-32.

McCormack, G. R., M. Rock, A. M. Toohey, and D. Hignell. 2010. Characteristics of urban parks as- 
sociated with park use and physical activity: A review of qualitative research. Health and Place 16(4): 712-726.

McDonald, N. C. 2007. Active transportation to school: Trends among US schoolchildren, 19692001. American Journal of Preventive Medicine 32(6): 509-516.

McLeroy, K. R., D. Bibeau, A. Steckler, and K Glanz. 1988. An ecological perspective on health promotion programs. Health Education Quarterly 15(4): 351-377.

McMillan, T. E. 2005. Urban form and a child's trip to school: The current literature and a framework for future research. Journal of Planning Literature 19(4): 440-456.

McMillan, T. E. 2007. The relative influence of urban form on a child's travel mode to school. Transportation Research Part A: Policy and Practice 41 (1): 69-79.

Mecredy, G., W. Pickett, and I. Janssen. 2011. Street connectivity is negatively associated with physical activity in Canadian youth. International Journal of Environmental Research and Public Health 8(8): $3333-3350$.

Mitra, R. 2013. Independent mobility and mode choice for school transportation: A review and framework for future research. Transport Reviews 33(1): 21-43.

Mitra, R., and R. N. Buliung. 2012. Built environment correlates of active school transportation: Neighborhood and the modifiable areal unit problem. Journal of Transport Geography 20(1): 51-61.

Mitra, R., and R. N. Buliung. 2014. The influence of neighborhood environment and household travel interactions on school travel behavior: An exploration using geographically-weighted models. Journal of Transport Geography 36: 69-78.

Moran, M. 2013. The relationship between the built environment and active living. $\mathrm{PhD}$ thesis. Haifa, Israel: Technion-Israel Institute of Technology.

Moudon, A. V., C. Lee, A, D. Cheadle, C. W. Collier, D. Johnson, T. L. Schmid, and R. D. Weather. 2005. Cycling and the built environment, a US perspective. Transportation Research Part D: Transport and Environment 10(3): 245-261.

Moudon, A.V., C. Lee, A. D. Cheadle, C. Garvin, D. Johnson, T. L. Schmid, R. D. Weathers, and L. Lin. 2006. Operational definitions of walkable neighborhood: Theoretical and empirical insights. Journal of Physical Activity and Health 3(S1): S99-S117.

Omer, I., Y. Rofe, Y. Lerman, Y. Cohen Y. 2012. A model to evaluate pedestrian volume in an urban environment. Presented at the Annual Conference of the Israeli Geographical Association, December 9-12, 2012. Ramat Gan, Israel: Bar-Ilan University.

Owen, N., I. De Bourdeaudhuij, T. Sugiyama, E. Leslie, E. Cerin, E., D. Van Van Dyck, and A. Bauman. 2010. Bicycle use for transport in an Australian and a Belgian city: Associations with builtenvironment attributes. Journal of Urban Health 87(2): 189-198.

Owen, N., N. Humpel, E. Leslie, A. Bauman, and J. F. Sallis. 2004. Understanding environmental influences on walking: Review and research agenda. American Journal of Preventive Medicine 27(1): $67-76$.

Page, A. S., A. R. Cooper, P. Griew, and R. Jago. 2010. Independent mobility, perceptions of the built environment and children's participation in play, active travel and structured exercise and sport: The PEACH Project. International Journal of Behavioral Nutrition and Physical Activity 7(1): 17.

PGL-Transportation Engineering and Planning. 2010. Traffic Counting for Rishon LeZion Master Plan 2030. Tel Aviv: PGL

Panter, J. R., A. P. Jones, E. M. Van Sluijs, and S. J. Griffin. 2010. Neighborhood, route, and school environments and children's active commuting. American Journal of Preventive Medicine 38(3): 268-278.

Parsons, T. J., C. Power, S. Logan, and C. D. Summerbell. 1999. Childhood predictors of adult obesity: A systematic review. International Journal of Obesity and Related Metabolic Disorders 23(8): S1-107. 
Raitakan, O. T., K. V. K. Porkka, S. Taimela, R. Telama, L. Räsänen, and J. S. Vllkari. 1994. Effects of persistent physical activity and inactivity on coronary risk factors in children and young adults the cardiovascular risk in young Finns study. American Journal of Epidemiology 140(3): 195-205.

Reed, J. A., A. E. Price, L. Grost, and K. Mantinan. 2012. Demographic characteristics and physical activity behaviors in sixteen Michigan parks. Journal of Community Health 37(2): 507-512.

Reed, J. A., and S. P. Hooker. 2012. Where are youth physically active? A descriptive examination of 45 parks in a southeastern community. Childhood Obesity (formerly Obesity and Weight Management) 8(2): 124-131.

Rishon LeZion Municipality. 2009. General Report for the Rishon LeZion Outline Plan 2030. Rishon LeZion, Israel: Rishon LeZion Municipality.

Rishon LeZion Municipality. 2013. The City's Neighborhoods: Statistical Data and Maps. Rishon LeZion, Israel: Rishon LeZion Municipality Research Center.

Roemmich, J. N., L. H. Epstein, S. Raja, and L. Yin. 2007. The neighborhood and home environments: Disparate relationships with physical activity and sedentary behaviors in youth. Annals of Behavioral Medicine 33(1): 29-38.

Saelens, B. E., and S. L. Handy. 2008. Built environment correlates of walking: a review. Medicine and Science in Sports and Exercise 40(7): S550.

Sallis, J. 2008. Angels in the details: Comment on the relationship between destination proximity, destination mix and physical activity behaviors. Preventive Medicine 14(1): 6-7.

Sallis, J. F., R. B. Cervero, W. Ascher, K. A. Henderson, M. K. Kraft, and J. Kerr. 2006. An ecological approach to creating active living communities. Annual Review of Public Health 27: 297-322.

Sallis, J. F., and K. Glanz. 2006. The role of built environments in physical activity, eating, and obesity in childhood. The Future of Children 16(1): 89־-108.

Sallis, J. F., and N. Owen. 1990. Ecological models of health behavior. In Health Behavior and Health Education, K. Glanz, B. K. Rimer, and F. M. Lewis, eds., pp. 462-482. San Francisco: Jossey-Bass.

Sallis, J. F., J. J. Prochaska, and W. C. Taylor. 2000. A review of correlates of physical activity of children and adolescents. Medicine and Science in Sports and Exercise 32(5): 963-975.

Staunton, C. E., D. Hubsmith, and W. Kallins. 2003. Promoting safe walking and biking to school: The Marin County success story. Journal Information 93(9): 1431-1434.

Stokols, D. 1992. Establishing and maintaining healthy environments: Towards a social ecology in health promotion. American Psychologist 47(1): 6-22.

Sugiyama, T., and C. Ward Thompson. 2008. Associations between characteristics of neighborhood open space and older people's walking. Urban Forestry and Urban Greening 7(1): 41-51.

Timperio, A., K. Ball, J. Salmon, R. Roberts, B. Giles-Corti, D. Simmons, L. A. Baur, and D. Crawford. 2006. Personal, family, social, and environmental correlates of active commuting to school. American Journal of Preventive Medicine 30(1): 45-51.

Timperio, A., D. Crawford, A. Telford, and J. Salmon. 2004. Perceptions about the local neighborhood and walking and cycling among children. Preventive Medicine 38(1): 39-47.

Transportation Research Board (TRB). 2005. Special Report 282: Does the Built Environment Influence Physical Activity? Examining the Evidence. Washington, DC: TRB.

Tranter, P., and J. Whitelegg. 1994. Children's travel behaviors in Canberra: Car-dependent lifestyles in a low-density city. Journal of Transport Geography 2(4): 265-273.

Trapp, G., B. Giles-Corti, H. Christian, M. Bulsara, A. Timperio, G. McCormack, and K. Villanueva. 2011. On your bike! A cross-sectional study of the individual, social and environmental correlates of cycling to school. International Journal of Behavioral Nutrition and Physical Activity 8: 123.

Tremblay, M. S., and J. D. Willms. 2003. Is the Canadian childhood obesity epidemic related to physi- 
cal inactivity? International Journal of Obesity 27(9): 1100-1105.

Tzafrir-Reoven, O. 2006. Spatial Patterns in the Israeli City. In The Israeli City: Last Hebrew City? I. Benyamini and I. Zivoni, eds., pp. 83-109. Tel-Aviv: Resling.

Underwood, S. K., S. L. Handy, D. A. Paterniti, and A. E. Lee. 2014. Why do teens abandon bicycling? A retrospective look at attitudes and behaviors. Journal of Transport \& Health 1(1): 17-24.

Valentine, G. 1997. Oh yes I can. Oh no you can't: Children and parents' understandings of kids' competence to negotiate public space safely. Antipode 29(1): 65-89.

Valentine, G., and J. McKendrck. 1997. Children's outdoor play: Exploring parental concerns about children's safety and the changing nature of childhood. Geoforum 28(2): 219-235.

Van Dyck, D., G. Cardon, B. Deforche, and I. De Bourdeaudhuij. 2009. Lower neighborhood walkability and longer distance to school are related to physical activity in Belgian adolescents. Preventive Medicine 48(6): 516-518.

Van Vliet, W. 1983. Children's travel behavior. Ekistics 50(298): 61-65.

Veitch, J., J. Salmon, and K. Ball. 2010. Individual, social and physical environmental correlates of children's active free-play: A cross-sectional study. International Journal of Behavioral Nutrition and Physical Activity 7(11): 1-10.

Wen, L. M., J. Kite, D. Merom, and C. Rissel. 2009. Time spent playing outdoors after school and its relationship with independent mobility: a cross-sectional survey of children aged 10-12 years in Sydney, Australia. International Journal of Behavioral Nutrition and Physical Activity 6: 15.

Zhu, X., and C. Lee. 2009. Correlates of walking to school and implications for public policies: Survey results from parents of elementary school children in Austin, Texas. Journal of Public Health Policy March 25, 2009: S177-S202. 